\title{
Pemberian Steroid pada Purpura Henoch- Schonlein serta Pola Perbaikan Klinis di Departemen IImu Kesehatan Anak FKUI/RSCM Jakarta
}

\author{
Mulya Safri, * Nia Kurniati, ** Zakiudin Munasir ** \\ *Bagian Ilmu Kesehatan Anak Fakultas Kedokteran Unsyiah / RSU Zainal Abidin Banda Aceh \\ **Departemen Ilmu Kesehatan Anak FKUI RS Dr. Cipto Mangunkusumo Jakarta
}

\begin{abstract}
Latar belakang. Purpura Henoch-Schonlein (PHS) merupakan penyakit vaskulitis yang relatif sering pada anak. Selama periode tahun 1998-2003 di Departemen IKA RSCM terdapat 23 kasus PHS. Pengobatan lebih bersifat simtomatik dan suportif. Pemberian steroid selama 5-7 hari menjadi pilihan pada gejala klinis yang berlanjut. Belum diketahui perjalanan penyakit pasien PHS yang mendapat terapi simtomatis maupun yang mendapat terapi steroid.

Tujuan. Mengetahui pola perbaikan klinis pasien PHS di Poliklinik Anak RSCM

Metode. Dilakukan penelitian deskriptif, Juli-Desember 2006, subjek penelitian kasus PHS di Poliklinik Alergi-Imunologi Anak RSCM.

Hasil. Didapatkan 10 kasus baru dengan usia rerata 5 tahun 4 bulan. Perbandingan laki-laki dan perempuan 1:4. Seluruh subjek mempunyai gejala purpura dan nyeri sendi. Nyeri perut didapatkan pada 9 subjek, keterlibatan ginjal 3, hipertensi dan hematuria 1, proteinuria 3, leukositosis dan trombosis pada 6 dan 3 subjek. Tujuh subjek mendapat imunomodulator. Perbaikan gejala berupa purpura, nyeri perut, nyeri sendi dan nefritis terjadi setelah 2 minggu, sisanya sebelum 2 minggu. Leukositosis dan trombosis membaik setelah 1-2 minggu. Tujuh subjek mendapat steroid setelah 1 minggu timbul gejala, 3 subjek mendapat triamsinolon dan sisanya metil prednisolon. Nyeri perut paling cepat menghilang pada subjek yang mendapat triamsinolon, sedangkan purpura pada yang mendapat metil prednisolon.

Kesimpulan. Terjadi peningkatan kasus PHS selama delapan bulan terakhir tahun 2006. Perbaikan gejala klinik mayoritas terjadi setelah 2 minggu mendapat pebgobatan steroid. Hal ini diperkirakan berhubungan dengan terlambatnya terapi steroid akibat pasien berobat dan penggunaan imunomodulator yang marak saat ini. (Sari Pediatri 2008;10(4):268-71).
\end{abstract}

Kata kunci: purpura Henoch-Schonlein, steroid, perbaikan klinis

\footnotetext{
Alamat Korespondensi:

Dr. Mulya Safri M.Kes Sp.A RSU Zainal Abidin, SMF IKA FK

UNSYIAH, Jl. Tgk H.M. Daud Bereuh No. 18 Banda Aceh.
} 
$\mathrm{P}$ urpura Henoch-Schonlein (PHS) adalah penyakit yang ditandai purpura, artritis, nyeri abdomen dan nefritis tanpa disertai trombositopenia. Manifestasi primer PHS terjadi akibat vaskulitis pada pembuluh darah kecil, sering dijumpai pada anak-anak. Etiologi belum diketahui, diperkirakan beberapa faktor berperan, yaitu genetik, lingkungan, infeksi, dan reaksi autoimun yang diperantarai imunoglobulin A. Kompleks antigen terdeposit di seluruh tubuh dan menjadi pencetus vaskulitis nekrotikans. ${ }^{1,2,3}$ Pemeriksaan laboratorium menunjukkan leukositosis dengan eosinofilia dan pergeseran hitung jenis ke kiri, dan trombositosis dijumpai pada $67 \%$ kasus. Urinalisis menunjukkan hematuria, kadang-kadang dapat dijumpai proteinuria, sedangkan ureum dan kreatinin dapat meningkat. Pemeriksaan feses menunjukkan adanya perdarahan. Imunoglobulin serum meningkat. ${ }^{1,2,3}$

Akhir-akhir ini kasus PHS di Departemen Ilmu Kesehatan Anak RSCM cenderung meningkat. Dari rekam medis RSCM tahun 1998-2003 didapatkan 23 kasus PHS anak dengan manifestasi gejala, purpura pada 23 anak, nyeri sendi 14 , nyeri perut 10 , perdarahan saluran cerna 3, dan nefritis 2 . Belum ada pengobatan spesifik untuk PSH, bersifat simtomatik dan suportif. Pemberian steroid seperti prednisolon atau triamsinolon selama 5-7 hari menjadi pilihan pada PHS, ${ }^{1,2,3}$ namun masa perbaikan gejala klinis sangat berbeda antara satu kasus dengan kasus yang lain. Saat ini diperkirakan infeksi, lambatnya pemberian steroid, dan pemberian imunomodulator yang marak pada anak di praktek dokter atau akibat iklan, menyebabkan penyakit ini meningkat dan penyembuhannya menjadi lebih lama. ${ }^{3,4}$

Tujuan penelitian untuk mengetahui prevalensi, karakteristik pasien dan pola perbaikan klinis dan laboratorium terhadap respon pengobatan PHS yang datang ke Poliklinik Anak RS Dr. Cipto Mangunkusumo Jakarta.

\section{Metode}

Penelitian deskriptif untuk melihat pola penyembuhan pasien PHS yang dirawat inap atau berobat jalan ke Poliklinik Alergi Imunologi Anak RSCM Jakarta, sejak tanggal 1 Juli 2006 sampai dengan 30 Febuari 2007.

Semua pasien yang memenuhi persyaratan penelitian dicatat umur, jenis kelamin, karakteristik gejala klinis data laboratorium serta riwayat pengobatan imunomodulator sebelum pasien menderita PHS. Diagnosis PHS ditegakkan berdasarkan American College of Rheumatology (ACR) tahun 1998. Gejala klinis yang dilihat yaitu purpura, artritis, nyeri perut, dan nefritis. Selanjutnya ditelusuri lama gejala klinis menghilang, saat dan jenis steroid yang diberikan pada pasien PHS.

\section{Hasil}

\section{Karakteristik subjek penelitian}

Selama kurun waktu penelitian didapatkan 10 kasus PHS yang berobat jalan di Poliklinik Anak RSCM. Usia rata-rata seluruh subjek penelitian 5,4 tahun dengan sebaran usia antara 3 tahun 8 bulan sampai dengan 9 tahun 9 bulan.

Subjek penelitian ini lebih banyak anak perempuan dibanding anak laki-laki, dengan perbandingan $4: 1$ (8 dan 2). Pada Tabel 1 tertera bahwa 7 subjek penelitian sering memakai imunomodulator, sedangkan sisanya tidak jelas apakah pernah mengkonsumsi obat jenis modulator oleh karena selama berobat ke dokter atau klinik semua obat dilepas labelnya.

Seluruh pasien PHS (10) mempunyai gejala klinis purpura dan nyeri sendi dan nyeri perut didapatkan pada 9 pasien (Tabel 2). Keterlibatan ginjal didapatkan pada 3 pasien, hipertensi dan hematuria pada 1 pasien, sedangkan proteinuria didapatkan pada 3 pasien, 6 pasien dengan leukositosis dan trombosis pada 3 pasien.

Tabel 1. Karakteristik subjek penelitian

\begin{tabular}{lc}
\hline Karakteristik & $\begin{array}{c}\text { Jumlah } \\
\mathrm{n}=10\end{array}$ \\
\hline $\begin{array}{l}\text { Usia rerata } \\
\text { rentang (tahun) }\end{array}$ & $(38 / 12-99 / 12)$ \\
Jenis kelamin & \\
- Laki-laki & \\
- Perempuan & 2 \\
Riwayat sering mendapat & 8 \\
imunomodulator & \\
- Ya & \\
- Tidak & 7 \\
- Tidak jelas & 0 \\
\hline
\end{tabular}


Perbedaan waktu perbaikan gejala klinis dan laboratorium setelah mendapat terapi steroid (Tabel 3). Gejala purpura menghilang sebagian besar terjadi 1 sampai 2 minggu setelah terapi, 7 di antaranya setelah 2 minggu dan 1 pasien $<1$ minggu. Nyeri sendi menghilang $<1$ minggu pada 5 pasien sedangkan sisanya $>2$ minggu.

Pada semua pasien yang mendapat triamsinolon, gejala nyeri perut menghilang sebelum 2 minggu, sedangkan menghilangya gejala purpura paling cepat pada pasien yang mendapat metil prednisolon. Lama gejala artritis dan nefritis menghilang tidak tampak perbedaan yang khas pada kedua pasien yang mendapat steroid sebelum 1 minggu sakit; perbaikan gejala klinis sebagian besar terjadi pada minggu kedua pemberian steroid, sedangkan 7 pasien yang mendapat steroid setelah 1 minggu sakit, dan rerata perbaikan klinis setelah 2 minggu.

\section{Pembahasan}

Purpura Henoch-Schonlein merupakan penyakit vaskulitis pada pembuluh darah berukuran kecil yang terjadi pada anak. ${ }^{1,2,3}$ Pada 8 bulan terakhir tahun 2007 di Departemen Ilmu Kesehatan Anak RS Dr. Cipto Mangunkusumo Jakarta (Juli 2006 sampai dengan Februari 2007) terdapat 10 kasus PHS dan jumlah meningkat dibandingkan periode lima tahun 19982003 didapatkan 23 kasus. Tahun 2002, Gardner dan Medwin melaporkan insiden PHS pada anak 20.4/ 100.000, yang juga cenderung meningkat dari tahun

Tabel 2. Gambaran klinis dan laboratorium saat datang

\begin{tabular}{lc}
\hline Gambaran klinis/laboratorium & $\begin{array}{c}\text { Jumlah } \\
(\mathrm{n}=10)\end{array}$ \\
\hline Purpura & 10 \\
Nyeri sendi & 10 \\
Nyeri perut & 9 \\
Perdarahan saluran cerna & 0 \\
Nefritis & 3 \\
- hipertensi & 1 \\
- hematuria & 1 \\
- proteinuria & 3 \\
Leukositosis & 6 \\
Trombositosis & 3 \\
\hline
\end{tabular}

Catatan: satu kasus dapat mempunyai gejala klinis lebih dari satu ke tahun. ${ }^{4}$ Bila dilihat dari Tabel 3, didapatkan bahwa usia rerata subjek penelitian PHS 5,4 tahun (3 tahun 8 bulan- 9 tahun 9 bulan). Jenis kelamin lebih banyak pada anak perempuan dibanding anak laki-laki (4:1), perbandingan ini tidak jauh berbeda dengan penelitianpenelitian yang telah dilapokan sebelumnya., 2,5

Melihat kecenderungan peningkatan insiden ini dicoba ditelusuri faktor mana yang lebih dominan dari beberapa faktor penyebab terjadinya penyakit ini. Beberapa faktor yang berperan yaitu genetik, lingkungan, infeksi, dan reaksi autoimun yang diperantarai imunoglobulin A. Kompleks antigen terdeposit di seluruh tubuh menjadi pencetus vaskulitis nekrotikans. ${ }^{1,2,3}$ Faktor infeksi dan reaksi autoimin diperkirakan lebih berperan saat ini, mengingat tingginya angka penyakit infeksi terutama infeksi virus. Gejala klinis yang telah dilaporkan dan yang kami temukan adalah purpura,

Tabel 3. Lama perbaikan gejala klinis dan laboratorium setelah mendapat terapi steroid

\begin{tabular}{|c|c|}
\hline Gambaran klinis/laboratorium & Jumlah $(\mathrm{n}=10)$ \\
\hline Purpura (minggu) & 10 \\
\hline$-<1$ & 1 \\
\hline$-1-2$ & 2 \\
\hline$->2$ & 7 \\
\hline Nyeri sendi (minggu) & 10 \\
\hline$-<1$ & 5 \\
\hline$-1-2$ & 0 \\
\hline$-\quad \geq 2$ & 5 \\
\hline Nyeri perut (minggu) & 9 \\
\hline$-<1$ & 0 \\
\hline$-1-2$ & 3 \\
\hline$-\quad \geq 2$ & 6 \\
\hline Nefritis (minggu) & 3 \\
\hline$-\quad<1$ & 0 \\
\hline$-1-2$ & 1 \\
\hline$-\quad \geq 2$ & 2 \\
\hline Leukositosis (minggu) & 6 \\
\hline$-<1$ & 0 \\
\hline$-1-2$ & 6 \\
\hline$-\quad \geq 2$ & 0 \\
\hline Trombositosis (minggu) & 3 \\
\hline$-<1$ & 0 \\
\hline$-1-2$ & 3 \\
\hline$->2$ & 0 \\
\hline \multicolumn{2}{|l|}{ Jenis terapi steroid } \\
\hline - Metil prednisolon & 7 \\
\hline - Triamsinolon & 3 \\
\hline \multicolumn{2}{|l|}{ Hari mendapat steroid (hari) } \\
\hline$-\leq 7$ & 3 \\
\hline$->7$ & 7 \\
\hline
\end{tabular}


nyeri sendi, nyeri perut, gangguan ginjal, leukositosis dan trombosis. ${ }^{2,5}$ Gejala klinis yang timbul sudah tampak sangat jelas dan tampak berat mengingat sebagian besar subjek penelitian datang berobat ke Poliklinik Anak Rumah Sakit Dr. Cipto Mangunkusumo Jakarta setelah minggu pertama perjalanan penyakit. Penyebab pasien datang terlambat berobat diperkirakan berhubungan dengan tingkat ekonomi dan pengetahuan masyarakat yang rendah. ${ }^{6}$

Pengobatan simtomatik dan suportif, serta pemberian steroid selama 5-7 hari menjadi pilihan. ${ }^{2,6,7}$ Penelitian Ronkainen dkk tahun 2005, menyimpulkan bahwa hari permulaan pemberian steroid saat diagnosis penyakit ditegakkan berperan dalam memperpendek masa perbaikan klinis PHS.7-10

Terdapat perbaikan klinis yang berbeda menurut saat pemberian steroid. Pada 7 kasus yang mendapat steroid setelah minggu kedua sakit, perbaikan gejala purpura, nyeri perut, nyeri sendi, dan nefritis umumnya terjadi setelah 2 minggu. Leukositosis dan trombosis membaik setelah 1-2 minggu. Jenis steroid yang diberikan pada pada subjek penelitian ini adalah triamsinolon dan sisanya metil prednisolon. Nyeri perut paling cepat menghilang pada subjek yang mendapat triamsinolon, sedangkan purpura pada yang mendapat metil prednisolon. Perbaikan yang cepat terhadap nyeri perut berhubungan dengan efek samping triamsinolon yang ringan terhadap saluran cerna. ${ }^{11,12}$

\section{Kesimpulan}

Telah terjadi peningkatan kasus PHS pada akhir tahun 2006. Perbaikan gejala klinik sebagian besar terjadi setelah 2 minggu mendapat steroid. Hal ini diperkirakan berhubungan dengan terlambatnya memulai terapi steroid. Angka kejadian infeksi virus yang tinggi pada anak, serta pengaruh iklan yang mengakibatkan penggunaan imunomodulator serta rutin, diperkirakan berhubungan insiden yang meningkat.

\section{Daftar pustaka}

1. Hurwitz S. Collagen vascular diseases of childhood. Pediatr Clin North Am 1991;38:1019-39.

2. Lanzkowsky S, Lanzkowsky L, Lanzkowsky P. Henoch schonlein purpura. Pediatr Rev 1992;13:130-7.

3. Cupps TR. Cardiac and vascular diseases. Dalam: Stites DP, Terr AI, penyunting. Basic and clinical immunology. Edisi ke-7. Norwalk: Appleton \& Lange; 1991.h. 495-6.

4. Gardner JMM, Dolezalova P, Southwood TR. Incidence of Henoch Schonlein purpura, Kawasaki diseases, and rare vasculitis in children different ethnic origins. Lancet 2002;360:1197-202.

5. Koskimies O, Mir S, Rapola J. Henoch Schoenlein nephritis longterm prognosis of unselected patients. Arch Dis Child 1981;56:482-4.

6. Cassidy JT, Petty RE. Leukocytoclastic vasculitis: Henoch-Schonlein purpura. Dalam: Cassidy JT, Petty RE, Laxer RM, penyunting. Textbook of pediatrics rheumatology. Edisi ke-5. Philadelphia: Elsevier Saunders; 2005.h.496-501.

7. Mollica F, Li Volti S, Garozzo R, Russo G. Effectiveness of early prednison treament in preventng the development of nephropathy in anaphylactoid purpura. Eur J Pediatr. 1992;151:140-4.

8. Rosenblom ND, Winter HS. Steroid effects on the course of abdominal pain in children with Henoch Schonlein Purpura. Pediatrics 1987;79:1018-21.

9. Buchanec J, Galanda V, Belakova S. Incidence of renal complication in Henoch Schonlein purpura syndrome in dependence of an early administration of steroids. Int Urol Nephrol 1988;20:409-12.

10. Amitai Y, Gillis D, Wasserman D, Kochman RH. Henoch-Schonlein purpura in infants. Pediatrics 1993;92:865-7.

11. Szer IS. Henoch-Schonlein purpura. Curr Opin Rheumatol 1994;6:25-31.

12. Tizard EJ. Henoch-Schonlein purpura. Arch Dis Child 1999;80:380-3. 